\title{
Evaluation of apoptosis and angiogenesis in ectopic and eutopic stromal cells of patients with endometriosis compared to non-endometriotic controls
}

Ali-Akbar Delbandi ${ }^{1,2}$, Mahmoud Mahmoudi ${ }^{2}$, Adel Shervin ${ }^{3}$, Sahel Heidari ${ }^{1}$, Roya Kolahdouz-Mohammadi ${ }^{4}$ and Amir-Hassan Zarnani ${ }^{3,5^{*}}$

\begin{abstract}
Background: Endometriosis is a chronic, painful, and inflammatory disease characterized by extra-uterine growth of endometrial tissues. Increased angiogenesis and resistance to apoptosis have been suggested to be involved in pathogenesis and development of endometriosis. The objective of this study was to examine apoptosis potential and angiogenesis contribution of eutopic (EuESCs) and ectopic (EESCs) endometrial stromal cells in patients with endometriosis compared to endometrial stromal cells from non-endometriotic controls (CESCs).

Methods: Stromal cells were isolated by enzymatic digestion of ectopic $(n=11)$ and eutopic $(n=17)$ endometrial tissues from laparoscopically-confirmed endometriotic patients. Endometrial stromal cells of 15 non-endometriotic patients served as control. Following cell characterization by immunofluorescent staining and flow cytometry using a panel of antibodies, the total RNA was isolated from the cultured cells, and analyzed for the expression of genes involved in apoptosis (BCl-2, BCl-xL, Bax, and caspase-3) and angiogenesis [vascular endothelial growth factor-A (VEGF-A) and hepatocyte growth factor (HGF)] by Real-time PCR.

Results: Significantly higher gene expression levels of BCl-2 and BCl-xL were found in EESCs compared with EuESCs and CESCs $(p<0.01)$. The gene expression of Bax in EESCs, EuESCs, and CESCs was not statistically significant. Furthermore, EuESCs exhibited a significantly lower caspase-3 gene expression compared with CESCs $(p<0.01)$ or EESCs $(p<0.05)$. Regarding angiogenesis, VEGF-A gene expression in EESCs $(p<0.001)$ and EuESCs $(p<0.05)$ were significantly higher compared with those of CESCs. EESCs exhibited a significantly higher HGF gene expression compared with EuESCs $(p<0.05)$.
\end{abstract}

Conclusions: These findings suggest reduced propensity to apoptosis and increased angiogenesis potential of EESCs, which may be involved in pathogenesis of endometriosis.

Keywords: Endometriosis, Apoptosis, Angiogenesis, Stromal cells, Ectopic

\footnotetext{
* Correspondence: zarnania@sina.tums.ac.ir; zarnania@gmail.com; zarnania@tums.ac.ir

${ }^{3}$ Reproductive Immunology Research Center, Avicenna Research Institute, ACECR, Tehran, Iran

${ }^{5}$ Department of Immunology, School of Public Health, Tehran University of

Medical Sciences, Tehran, Iran

Full list of author information is available at the end of the article
}

(c) The Author(s). 2020 Open Access This article is distributed under the terms of the Creative Commons Attribution 4.0 International License (http://creativecommons.org/licenses/by/4.0/), which permits unrestricted use, distribution, and reproduction in any medium, provided you give appropriate credit to the original author(s) and the source, provide a link to the Creative Commons license, and indicate if changes were made. The Creative Commons Public Domain Dedication waiver (http://creativecommons.org/publicdomain/zero/1.0/) applies to the data made available in this article, unless otherwise stated. 


\section{Background}

Endometriosis, defined as settlement of endometrial glands and stroma in the extra-uterine cavity, is associated with irregular uterine bleeding, infertility, dyspareunia, and chronic pelvic pain [1]. The highest prevalence rates are typically found in couples with fertility problems (5-50\%), while it affects $10-20 \%$ of reproductive-aged women [2]. Despite being quite common among women, our current understanding of the etiology and pathophysiology of endometriosis is unknown [3]. Several theories have been developed to address the pathogenesis of endometriosis, but the retrograde menstruation proposed by Sampson in 1927 is the most widely accepted one [4]. According to this theory, uterine endometrial cells refluxed through fallopian tubes into the peritoneal cavity during menstruation, implant and initiate the endometriotic lesion formation. Therefore, endometrial cells are likely to play an important role in the establishment of the disease [5].

Most recent reports have revealed an increased survival capability of ectopic (EESCs) and eutopic endometrial stromal cells (EuESCs) from patients with endometriosis compared with cells from non-endometriotic women [6]. Higher capacity for survival and proliferation, and resistance to apoptosis have been suggested to be involved in implantation of these cells in patients with endometriosis [6-8].

Apoptosis, maintains cellular homeostasis through elimination of excess or dysfunctional cells from the functional layer of the uterine endometrium during the late secretory and menstrual phases of the menstrual cycle [9]. Apoptotic activity of endometriotic cells is regulated by a diversity of regulatory factors. Among these regulators, both anti-apoptotic (e.g. B-cell lymphoma/ leukemia-2 gene (Bcl-2) and B-cell lymphoma-extra large $(\mathrm{Bcl}-\mathrm{xL})$ ) and pro-apoptotic factors (e.g. Bax and caspase-3) play a critical role in this process [9]. Several studies pointed that endometrium from endometriotic patients is less sensitive to apoptosis than that from healthy controls $[10,11]$.

Besides of apoptosis resistance, endometriotic lesions have been indicated to be highly vascularized with new vessels that are essential for the successful implantation of endometrial cells at ectopic sites [12]. The vascular endothelial growth factor-A (VEGF-A) is a potent angiogenic factor that induces endometrial cell proliferation and is considered an important factor in uterine angiogenesis [13]. Apart from VEGF-A, hepatocyte growth factor (HGF), as a pleiotropic cytokine, has angiogenic, mitogenic, and motogenic activities all of these may be involved in the pathogenesis of endometriosis [14].

According to these arguments, here we assessed expression of some genes actively involved in regulation of apoptosis (Bcl-2, Bcl-xL, Bax, and caspase-3) and angiogenesis (VEGF-A and HGF) in EuESCs, EESCs and endometrial stromal cells from non-endometriotic controls (CESCs).

\section{Materials and methods \\ Patients}

The study group included twenty-five women with ovarian endometriosis (mean age: $29 \pm 7$ years) and twenty with benign gynecological conditions (mean age: $32 \pm 6$ years). Endometriosis in patient groups was confirmed by laparoscopy and pathological examination. Participants in the control group did not exhibit any endometriotic lesions as carefully evidenced by a laparoscopic surgeon. All of the subjects were at the proliferative phase of the menstrual cycle with regular menstrual cycles and none of them were on or had received any hormonal or immunomodulatory treatment within 3 months before surgery. Patients with pelvic inflammatory disease, adenomyosis, and any malignancy or autoimmune disorders were excluded. All laparoscopic procedures were done by the same experienced gynecological surgeon. When endometriosis was diagnosed, the stage of the disease was determined according to the revised American Society for Reproductive Medicine classification system (ASRM 1996). Only women with endometrioma who were at stage III-IV were chosen for the study.

This study was approved by the Institutional Review Board and the Ethics Committee for Medical Research of the Avicenna Research Institute and all participants signed written informed consent before participating in the study.

\section{Sample collection}

The ectopic endometrial tissues were taken through laparoscopy and eutopic samples were collected by biopsy curette. All of the endometrial samples were immediately transferred to the laboratory in tissue culture medium containing antibiotics, frozen in freezing medium containing Dulbecco's modified Eagle's medium (DMEM)-F12 (Sigma, USA), 10\% fetal bovine serum (FBS; Sigma, USA), and 20\% dimethyl sulfoxide (Sigma, USA) at $-80^{\circ} \mathrm{C}$ and stored in liquid nitrogen until stromal cell isolation. A fraction of each tissue was sent for pathological confirmation of endometrioma.

From 25 endometriosis patients and 20 control patients, some samples were excluded from the study as a result of tissue contamination, inconsistent pathology report or absence of enough cell growth especially in case of EESCs. Finally, cells from 17 eutopic and 11 ectopic endometrial tissues of endometriotic patients and 15 eutopic endometrial tissue from non-endometriotic patients were used in this study. 
Isolation and culture of endometrial stromal cells (ESCs) As previously described [15], ectopic and eutopic endometrial tissues of patients with ovarian endometriosis and eutopic endometrial tissues from control subjects were thawed and digested at $37^{\circ} \mathrm{C}$ for $1.5-2 \mathrm{~h}$ in the presence of collagenase $\mathrm{A}$ and DNAse (Roche, USA). The obtained single cells were cultured, and nonadherent cells were removed by washing, and adherent cells were allowed to grow and reach to approximately $80 \%$ confluence. The identity and purity of the ESCs were evaluated by flow cytometry and immunofluorescent staining using a panel of antibodies against CD9, CD10, CD29, CD34, CD38, CD44, CD45, CD73, CD105, CD133 (all from Becton Dickinson Biosciences, USA), FITC-vimentin, FITC-cytokeratin (both from Abcam, USA), and PE-nestin (R\&D Systems, USA) as described elsewhere [15].

\section{Quantitative real-time polymerase chain reaction}

Total RNA of the ESCs was isolated according to the protocol supplied with RNA-Bee Reagent (BioSite, Sweden) according to the manufacturer's instruction. The purity and concentration of RNA samples were determined using PicoDrop spectrophotometer (Picopetol, UK). One microgram of total RNA was reverse transcribed to complementary DNA (cDNA) according to the protocol published elsewhere [16]. The beta-actin gene was used as an internal control. Real-time PCR analyses were carried out with the SYBR green dyebased detection system (Takara, Japan) using the ABI 7500 thermocycler with fluorescence detection (Applied Biosystems, USA). Reactions were denaturated at $95^{\circ} \mathrm{C}$ for $10 \mathrm{~s}$, followed by 40 cycles of $95^{\circ} \mathrm{C}$ for $5 \mathrm{~s}, 34 \mathrm{~s}$ of extension at $60^{\circ} \mathrm{C}$ and finally a dissociation step consisting of $95^{\circ} \mathrm{C}$ for $15 \mathrm{~s}, 60^{\circ} \mathrm{C}$ for $1 \mathrm{~min}, 95^{\circ} \mathrm{C}$ for $15 \mathrm{~s}$, and $60^{\circ} \mathrm{C}$ for $15 \mathrm{~s}$. At the end of the program, a melting curve analysis was done and the PCR products were also analyzed using gel electrophoresis to ensure the accuracy of the amplifications. Reactions were done independently in triplicate. The primer sequences and the size of amplicons are shown in Table 1. The relative gene expression of apoptosis and angiogenesis genes were calculated by LinRegPCR.11.0 and REST software (REST - version 2009).

\section{Statistical analysis}

In this study we used REST software (version 2009) to test the group difference for significance using the Pair Wise Fixed Reallocation Randomization Test. Expression of each gene in each individual sample was first normalized to the corresponding housekeeping gene and then the ratio of normalized gene expression was compared between two groups. Data were expressed as mean \pm standard error. A $p<0.05$ was considered significant.
Table 1 Specifications of the primers used in this study

\begin{tabular}{|c|c|c|c|}
\hline Target gene & Accession No. & Sequence $5^{\prime}$ to $3^{\prime}$ & Amplicon size (bp) \\
\hline$\overline{B C l}-2-\mathrm{F}$ & $\begin{array}{l}\text { BC027258, } \\
\text { NM_000633, } \\
\text { NM_000657 }\end{array}$ & $\begin{array}{l}\text { ATCGCCCTGTGG } \\
\text { ATGACTGAGT }\end{array}$ & 127 \\
\hline $\mathrm{BCl}-2-\mathrm{R}$ & & $\begin{array}{l}\text { GCCAGGAGAAA } \\
\text { TCAAACAGAGGC }\end{array}$ & \\
\hline$B C l-x L-F$ & $\begin{array}{l}\text { NM_001191, } \\
\text { NM_138578 }\end{array}$ & $\begin{array}{l}\text { GCCACTTACCTG } \\
\text { AATGACCACC }\end{array}$ & 131 \\
\hline$B C l-X L-R$ & & $\begin{array}{l}\text { AACCAGCGGTTG } \\
\text { AAGCGTTCCT }\end{array}$ & \\
\hline Bax-F & $\begin{array}{l}\text { NM_001291428, } \\
\text { NM_001291429, } \\
\text { NM_001291430, } \\
\text { NM_001291431 }\end{array}$ & $\begin{array}{l}\text { TCAGGATGCGT } \\
\text { CCACCAAGAAG }\end{array}$ & 103 \\
\hline Bax-R & & $\begin{array}{l}\text { TGTGTCCACGG } \\
\text { CGGCAATCATC }\end{array}$ & \\
\hline Caspase-3-F & $\begin{array}{l}\text { NM_004346, } \\
\text { NM_032991 }\end{array}$ & $\begin{array}{l}\text { GGAAGCGAATC } \\
\text { AATGGACTCTGG }\end{array}$ & 146 \\
\hline Caspase-3-R & & $\begin{array}{l}\text { GCATCGACATCT } \\
\text { GTACCAGACC }\end{array}$ & \\
\hline VEGF-A-F & $\begin{array}{l}\text { AF022375, } \\
\text { NM_001025366, } \\
\text { NM_001025367, } \\
\text { NM_001025368 }\end{array}$ & $\begin{array}{l}\text { TTGCCTTGCTGCT } \\
\text { CTACCTCCA }\end{array}$ & 126 \\
\hline VEGF-A-R & & $\begin{array}{l}\text { GATGGCAGTAGC } \\
\text { TGCGCTGATA }\end{array}$ & \\
\hline HGF-F & $\begin{array}{l}\text { NM_001010932.2, } \\
\text { NM_000601.5 }\end{array}$ & $\begin{array}{l}\text { GCAATTAAAACA } \\
\text { TGCGCTGACA }\end{array}$ & 140 \\
\hline HGF-R & & $\begin{array}{l}\text { TCCCAACGCTG } \\
\text { ACATGGAAT }\end{array}$ & \\
\hline$\beta$-Actin-F & P60709 & $\begin{array}{l}\text { AGC CTC GCC T } \\
T T \text { GCC GA }\end{array}$ & 174 \\
\hline$\beta$-Actin-R & & $\begin{array}{l}\text { CTG GTG CCT G } \\
\text { GG GCG }\end{array}$ & \\
\hline
\end{tabular}

\section{Results}

ESCs exhibited a fibroblast-like appearance throughout the culture period. The flow cytometric analysis showed that isolated ESCs express mesenchymal origin antigens such as CD9, CD29, CD44, CD73, and CD105 but were negative for other origin markers, including CD34, CD38, CD133, and CD45 (Fig. 1A). Immunofluorescence staining of the propagated cells from all three sources showed positive results for vimentin, a stromal cell cytoskeletal marker, and nestin but negative signal for cytokeratin, an epithelial marker (Fig. 1B), suggesting purity of the isolated cells [15].

\section{Expression of apoptosis and angiogenesis related gene}

The gene expression levels of apoptosis and angiogenesis were examined using real time PCR. Our results showed significantly higher gene expression levels of Bcl-2 (Fig. 2a) and Bcl-xL (Fig. 2b) in EESCs compared to EuESCs or CESCs $(p<0.01)$. Besides, EuESCs showed elevated levels of $\mathrm{Bcl}-\mathrm{xL}$, but not $\mathrm{Bcl}-2$, gene expression 
(A)
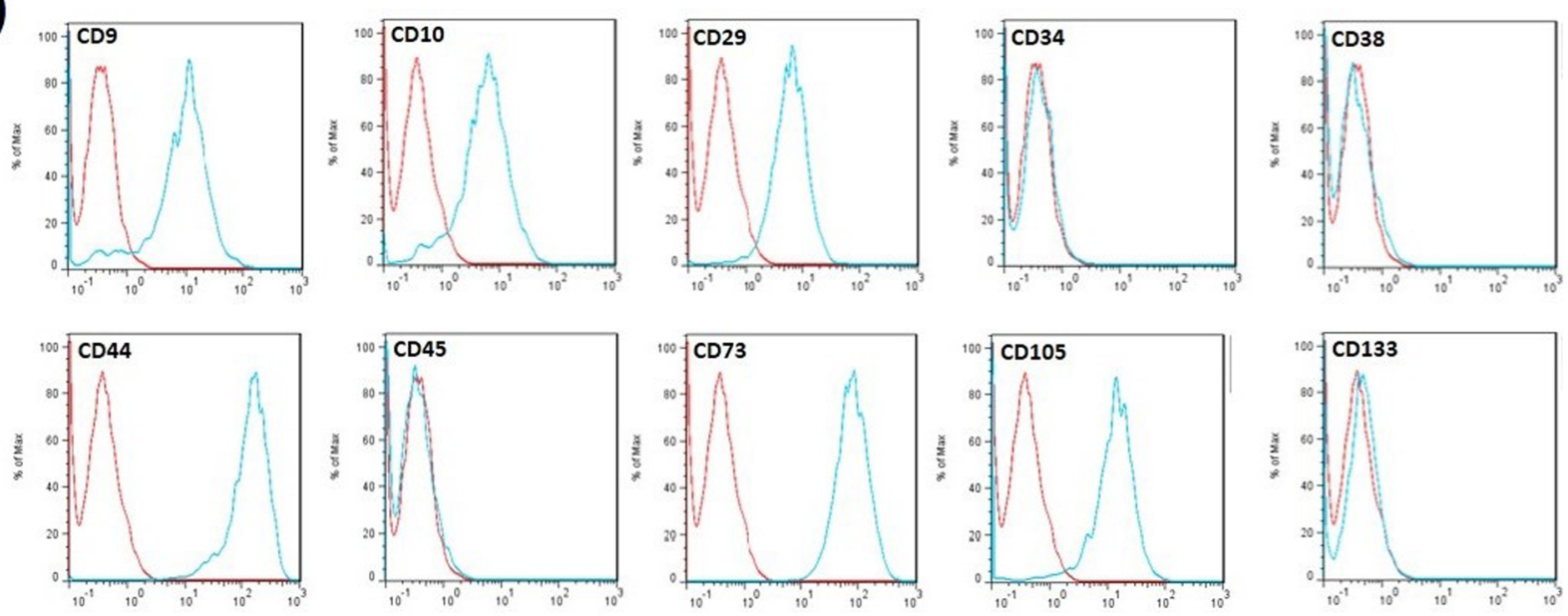

(B)
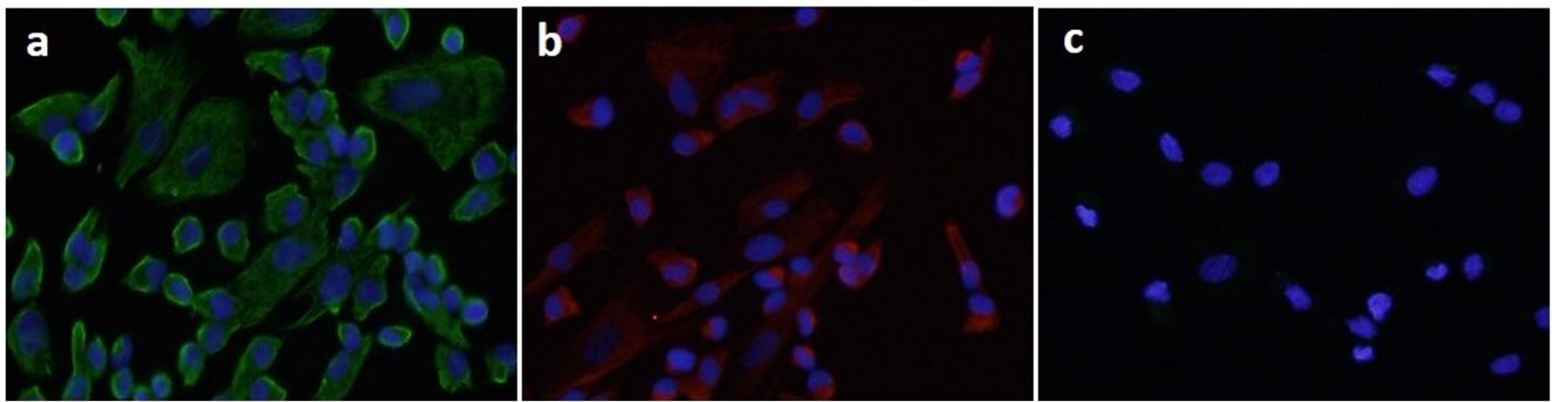

Fig. $1 \mathrm{Immunophenotyping} \mathrm{of} \mathrm{ESCs} \mathrm{of} \mathrm{the} \mathrm{study} \mathrm{groups} \mathrm{characterized} \mathrm{by} \mathrm{flow} \mathrm{cytometric} \mathrm{analysis} \mathrm{and} \mathrm{immunofluorescent} \mathrm{staining.} \mathrm{(A)}$ Representative flow cytometric analysis of CD9, CD10, CD29, CD34, CD38, CD44, CD45, CD73, CD105, and CD133 markers in ESCs. (B) Representative immunofluorescent staining of ESCs exhibiting the expression of vimentin (a) and nestin (b) and negative immunoreactivity for cytokeratin (c). ESCs from all three sources exhibited the same pattern

compared with CESCs $(p<0.05)$ (Fig. $2 \mathrm{~b}$ and a respectively). The difference of Bax gene expression between EESCs, EuESCs, and CESCs was not statistically significant (Fig. 2c). In addition, EuESCs showed a significantly lower caspase-3 gene expression compared with CESCs $(p<0.01)$ or EESCs $(p<0.05)$, but the difference between EESCs and CESCs was not significant (Fig. 2d). VEGF-A gene expression by EESCs and EuESCs were statistically higher compared with those of CESCs $(p<0.001$ and $p<0.05$, respectively). Although EESCs showed increased VEGF-A gene expression compared to EuESCs, but the difference was not significant (Fig. 3a). HGF gene expression by EESCs was statistically higher compared with EuESCs $(p<0.05)$ (Fig. 3b).

\section{Discussion}

Endometriosis is a benign disease characterized by the accumulation of cells in ectopic sites that could result from either increased angiogenesis or the deficiency of cells to undergo apoptosis [17].
Apoptosis is a form of programmed cell death that removes old layers of functional endometrial cells at the late menstruation secretory phase and in this way maintains cellular homeostasis in the menstrual cycle [18]. The results of our study showed significantly higher gene expression levels of anti-apoptotic proteins, $\mathrm{Bcl}-2$ and Bcl-xL, in EESCs compared with EuESCs or CESCs. The pro-apoptotic caspase-3 gene revealed lower expression levels in EuESCs compared with CESCs or EESCs. In addition, the difference of Bax gene expression between ESCs from all three sources was not statistically significant. Extrinsic and intrinsic apoptotic pathways may be involved in the pathogenesis of endometriosis [19]. FasL/Fas interaction in extrinsic pathway leads to a cascade of activation of initiator (caspase-8 and -9) and effector

(caspase-3, - 6 and/or - 7) caspases, and finally apoptosis [19]. In a study by Nisio et al. caspase- 8 but not caspases 9 and 3 overexpressed in cortical tissue surrounding endometriotic cysts and not cortex around other benign cysts. These findings suggested that altered 
(a)

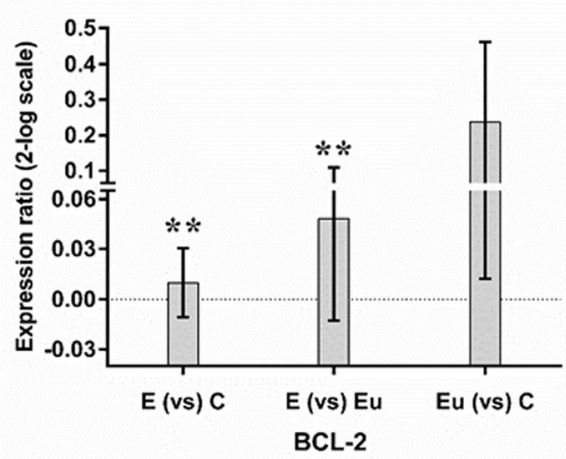

(c)

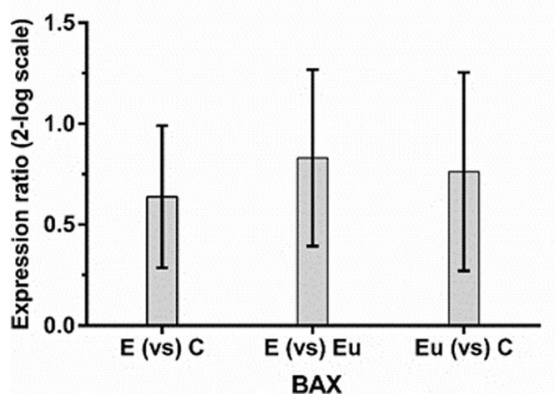

(b)

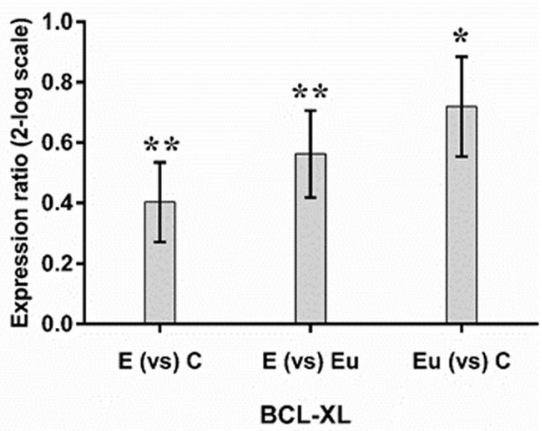

(d)

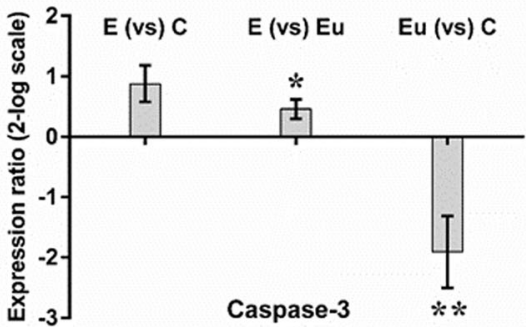

Fig. $2 \mathrm{BCl}-2(\mathbf{a}), \mathrm{BCl}-\mathrm{xL}(\mathbf{b}), \mathrm{Bax}(\mathbf{c})$, and caspase-3 (d) gene expression of isolated endometrial cells of studied groups. Each bar represents levels of $\mathrm{BCl}-2, \mathrm{BCl}-\mathrm{xL}, \mathrm{Bax}$, and caspase-3 gene expression in two different endometrial stromal cell groups. $17 \mathrm{Eu}, 11 \mathrm{E}$ and $15 \mathrm{C}$ were used in this study. Data are expressed as mean \pm standard error. E, stromal cells from the ectopic endometrium of patients with endometriosis (endometrioma); Eu, stromal cells from the eutopic endometrium of patients with endometriosis; $C$, stromal cells from non-endometriotic controls, ${ }^{*} p<0.05,{ }^{* *} p<0.01$

cellular microenvironment could induce cellular damage of normal tissue around endometriotic cyst [20]. Besides, few studies have investigated Fas expression in endometriotic tissues. In a study by Harada et al., Fas showed random expression in both eutopic and ectopic endometrial tissues and authors suggested that Fas may be less involved as an apoptosis regulator in both eutopic and ectopic endometrial tissues [21]. On the other hand, increased levels of inflammatory cytokines [22], growth factors [23], and especially soluble/active FasL [24] have been demonstrated in peritoneal fluid (PF) of women with moderate to severe endometriosis compared to women with early-stage disease or disease-free women. Increased levels of soluble/active FasL in PF of endometriotic patients may contribute to increased apoptosis of Fas-bearing immune cells [24]. Furthermore, in studies by Garcia-Velasco et al. [25] and Selam et al. [26], increased levels of platelet-derived growth factor (PDGF), transforming growth factor- $\beta$ (TGF- -3 ), and IL-8 induced expression of FasL by endometriotic stromal cells. The authors speculated that elevated PF levels of these factors induces apoptosis of immune cells but not endometriotic tissues via stimulation of FasL/Fas interaction. So based on the above findings it seems that FasL/Fas mediated apoptosis pathway is not efficient in elimination of endometriotic implants. Nevertheless, further studies are needed to investigate FasL/Fas expression in endometrial and endometriotic tissues. So in this study we aimed to investigate gene expression of factors involved in intrinsic pathway of apoptosis.

Several gene expression studies related to apoptosis were done on human endometrial cells during the different phases of the menstrual cycle. These studies provided conflicting data regarding the difference in gene expression levels involved in apoptosis between normal endometrial tissue and endometrial tissue in women with endometriosis [7, 27]. Although a large number of studies have examined apoptosis through regulation of Bcl-2 expression in endometriosis and a relatively few studies have examined apoptosis through regulation of Bax expression in endometriosis, very few studies have monitored apoptosis through regulation of caspase-3 and $\mathrm{Bcl}-\mathrm{xL}$ expression in endometriosis. With regard to apoptosis, many studies showed an inverse correlation 


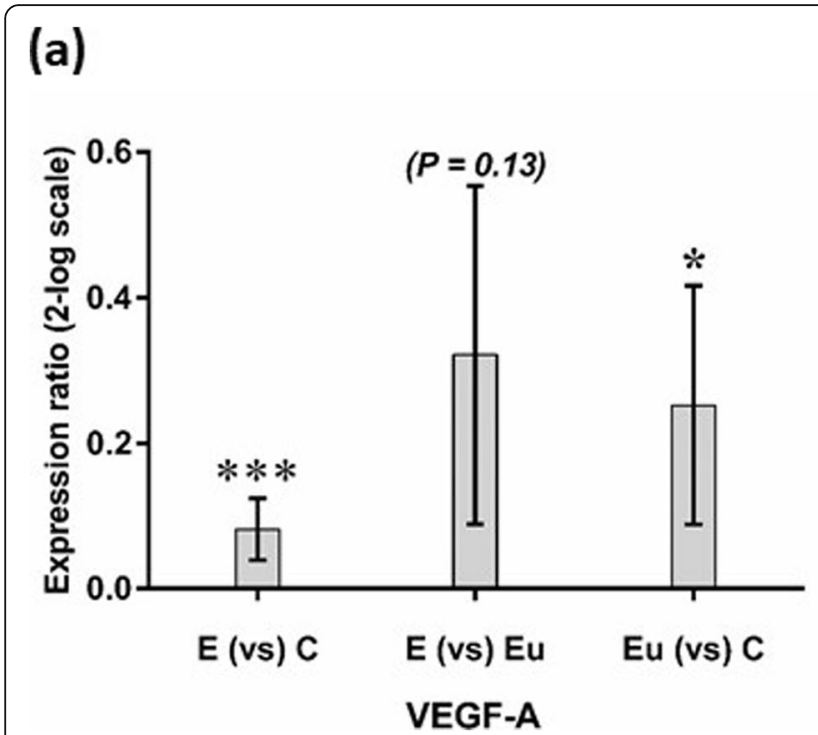

(b)

Fig. 3 VEGF-A (a) and HGF (b) gene expression of isolated endometrial cells of studied groups. Each bar represents levels of VEGF-A and HGF gene expression in two different endometrial stromal cell groups. $17 \mathrm{Eu}, 11 \mathrm{E}$ and $15 \mathrm{C}$ were used in this study. Data are expressed as mean \pm standard error. E, stromal cells from the ectopic endometrium of patients with endometriosis (endometrioma); Eu, stromal cells from the eutopic endometrium of patients with endometriosis; $C$, stromal cells from non-endometriotic controls. ${ }^{*} p<0.05,{ }^{* * *} p<0.001$

between the level of apoptosis and the stage of the disease $[11,28]$. The $\mathrm{Bcl}-2$ protein is probably the best protein for investigating apoptosis. Previous studies have provided conflicting results regarding the difference in Bcl-2 expression between normal endometrial tissue and endometrial tissue in women with endometriosis. According to published studies, $\mathrm{Bcl}-2$ was negative in most of the ectopic endometrial tissues from endometrioma $[21,29]$ and in another study, Bcl-2 expression was not different between endometrial tissues of endometriotic women and control counterparts [27, 30], but it was significantly expressed to a greater extent in stromal cells from ectopic tissues in another study [31]. On the other hand, in a study by Meresman et al., an increased expression of Bcl-2 protein was found in eutopic endometrium from women with endometriosis compared to the control group only in late proliferative phase [17]. Similarly to Jones et al. [31] study, in our study, Bcl-2 expression was increased significantly in EESCs.

Regarding Bcl-xL, gene expression of this antiapoptotic protein was not different between women with endometriosis compared to healthy controls [32]. On the contrary, we found increased mRNA expression of Bcl-xL gene in EESCs compared with EuESCs and CESCs. Apart from anti-apoptotic proteins, proapoptotic proteins such as Bax and caspase- 3 may have fundamental roles in pathogenesis of endometriosis. Bax gene is one of the well-characterized pro-apoptotic genes, antagonizes the prosurvival activity of Bcl-2 [33]. Goumenou et al., found a strong inverse correlation between $\mathrm{Bax}$ and $\mathrm{Bcl}-2$ expression in endometrioma [34].
In our study, we observed no statistically significant differences between EESCs, EuESCs, and CESCs in terms of Bax gene expression. Similarly, in previous studies, the Bax gene expression did not differ between endometrium from women with endometriosis and controls $[17,27,30,32]$. This finding may imply that not all genes involved in regulation of apoptosis are modulated in patients with endometriosis.

Caspase- 3 is a member of the cysteine protease family, plays a fundamental role in the activation of apoptosis [35]. We studied caspase-3 gene expression in ESCs because of its important role in apoptosis but more so because in several of the studies related to endometriosis that we studied it was altered or lost. In our study caspase-3 gene expression was significantly lower in EuESCs compared to CESCs. Similarly, in a study by Wei et al., significantly lower expression of caspase-3 protein was found in ectopic and eutopic endometrium of patients with endometriosis as compared with the control group [36]. The discrepancy between results in different studies could be explained by: 1) the properties of separated cells (glandular versus stromal cells), 2) the use of different endometriotic lesions (peritoneal versus ovarian endometriosis), 3) various PCR techniques, 4) difference in the preparation of cell and tissue culture conditions, 5) difference in age and sexual phase of patients, and 6) difference in the stage of disease and in the number of subjects.

In general, with regard to above findings, increased gene expression of $\mathrm{Bcl}-2$ and $\mathrm{Bcl}-\mathrm{xL}$ as anti-apoptotic proteins in EESCs and decreased gene expression of 
caspase-3 in EuESCs, may hamper apoptosis and lead to abnormal cell growth in ectopic locations and the development of endometriosis.

Regardless of the apoptosis, angiogenesis has an essential role in the establishment and growth of endometriotic lesions. The highly regulated angiogenesis is responsible for maintaining normal reproduction and endometrial growth and remodeling [12]. VEGF-A as one of the most potent angiogenic factors, has a critical role in physiological and pathological angiogenesis [37]. VEGF-A production is stimulated by growth factors, hormones, cytokines, and hypoxia [38] and sources of this factor in endometriosis include ectopic endometrium and peritoneal macrophages [39]. Numerous studies have shown significantly increased VEGF levels in the $\mathrm{PF}$ of endometriotic patients compared to controls $[40,41]$. Regarding VEGF-A gene expression, some studies showed unchanged [40,42, 43], while other studies showed increased VEGF-A gene expression in eutopic or ectopic endometrium of women with endometriosis compared to endometrium of non-endometriotic women [44-48]. However, only one study investigated VEGF-A expression in ESCs and in that study, VEGF-A expression was not different between EuESCs and CESCs [49]. Our results showed the increased VEGF-A gene expression in EESCs and EuESCs compared to CESCs. Discrepancy in mentioned findings might be attributed to difference in phases of the menstrual cycle as in a study by Danastas et al. [44], VEGF-A gene expression was significantly higher during menstruation than other phases. Besides, type of endometriotic lesions affects VEGF-A gene expression as higher VEGF-A gene expression was observed in highly vascularized red peritoneal lesions than black ones [12]. Genetic also plays a fundamental role in this regard as some polymorphisms of the VEGF gene might be protective or destructive for endometriosis [50].

Another important angiogenic factor is HGF. Lipopolysaccharides (LPS), inflammatory cytokines, and prostaglandins stimulate HGF production in pelvic cavity of endometriotic patients [51] and the peritoneum and endometriotic stromal cells seem to be primary sources of HGF in endometriosis [51, 52]. Increased HGF expression has been shown in ectopic compared to eutopic endometrial tissue in patient with endometriosis [43] or non-endometriotic patients [53]. Regarding ESCs, one study showed increased HGF protein expression in EuESCs compared to CESCs [54] and in line with our findings, in a study by Arablou et al. HGF gene expression was higher in EESCs compared to EuESCs [55].

HGF and its receptor c-met were shown to enhance the degradation of extracellular matrix (ECM) and stimulate invasion of shed eutopic and ectopic endometrium via autocrine and paracrine pathways [56]. Besides,
HGF has been shown to promote VEGF-A-driven angiogenesis [57]. So these findings imply that HGF may play a role in the pathogenesis of endometriosis.

\section{Conclusion}

The present study demonstrated that not only less susceptibility of EESCs and EuESCs to apoptosis, but also increased angiogenesis of these cells may result in their continuing growth into ectopic locations and would be fundamental to the pathophysiology of endometriosis thus further investigations on apoptosis and angiogenesis of EESCs and EuESCs compared to control groups are needed to clarify the roles of these factors in the development of endometriosis.

\section{Abbreviations}

ASRM: American Society for Reproductive Medicine; Bcl-2: B-cell lymphoma/ leukemia-2; Bcl-xL: B-cell lymphoma-extra Large; cDNA: complementary DNA; CESCs: Control Endometrial Stromal Cells; DMEM-F12: Dulbecco's Modified Eagle's Medium-F12; ECM: Extracellular Matrix; EESCs: Ectopic Endometrial Stromal Cells; ESCs: Endometrial Stromal Cells; EuESCs: Eutopic Endometrial Stromal Cells; FBS: Fetal Bovine Serum; HGF: Hepatocyte Growth Factor; LPS: Lipopolysaccharides; PDGF: Platelet-Derived Growth Factor; PF: Peritoneal Fluid; TGF-ß: Transforming Growth Factor-B; VEGF-A: Vascular Endothelial Growth Factor-A

\section{Acknowledgements}

We thank all of the patients for participating in this study and Iran University of Medical Sciences for partial financial support (grant No: 27011-138-04-94).

\section{Authors' contributions}

$A A D, M M$, and $A H Z$ contributed to conception and design, acquisition, analysis and interpretation of data. AAD carried out all the experiments described in the manuscripts. ASH contributed to conception and design of study and provided all tissues. SH and RKM wrote the manuscript. All authors read and approved the final manuscript.

\section{Funding}

This work was supported by grants from Avicenna Research Institute and Mashhad.

University of Medical Sciences.

\section{Availability of data and materials}

The datasets used and/or analyzed during the current study are available from the corresponding author on reasonable request.

\section{Ethics approval and consent to participate}

This study was approved by the Institutional Review Board and the Ethics Committee for Medical Research of the Avicenna Research Institute and all participants signed written informed consent before participating in the study.

Consent for publication

Not applicable

\section{Competing interests}

The authors declare that they have no competing interests.

\section{Author details}

${ }^{1}$ Immunology Research Center, Immunology and Infectious Disease Institute, Iran University of Medical Sciences, Tehran, Iran. ${ }^{2}$ Immunology Research Center, School of Medicine, Mashhad University of Medical Sciences, Mashhad, Iran. ${ }^{3}$ Reproductive Immunology Research Center, Avicenna Research Institute, ACECR, Tehran, Iran. ${ }^{4}$ Department of Nutrition, School of Public Health, Iran University of Medical Sciences, Tehran, Iran. ${ }^{5}$ Department of Immunology, School of Public Health, Tehran University of Medical Sciences, Tehran, Iran. 
Received: 28 August 2019 Accepted: 12 December 2019

\section{Published online: 06 January 2020}

\section{References}

1. Eskenazi B, Warner ML. Epidemiology of endometriosis. Obstet Gynecol Clin N Am. 1997;24(2):235-58.

2. Mcleod BS, Retzloff MG. Epidemiology of endometriosis: an assessment of risk factors. Clin Obstet Gynecol. 2010;53(2):389-96.

3. Kennedy S, Bergqvist A, Chapron C, D'hooghe T, Dunselman G, Greb R, et al. ESHRE guideline for the diagnosis and treatment of endometriosis. Hum Reprod. 2005;20(10):2698-704.

4. Sampson JA. Benign and malignant endometrial implants in peritoneal cavity, and their relation to certain ovarian tumors. Surg Gynecol Obstet. 1924;38:287-311.

5. Sacco K, Portelli M, Pollacco J, Schembri-Wismayer P, Calleja-Agius J. The role of prostaglandin E2 in endometriosis. Gynecol Endocrinol. 2012;28(2):134-8.

6. Nasu K, Nishida M, Kawano Y, Tsuno A, Abe W, Yuge A, et al. Aberrant expression of apoptosis-related molecules in endometriosis: a possible mechanism underlying the pathogenesis of endometriosis. Reprod Sci. 2011;18(3):206-18.

7. Harada T, Kaponis A, Iwabe T, Taniguchi F, Makrydimas G, Sofikitis N, et al. Apoptosis in human endometrium and endometriosis. Hum Reprod Update. 2004;10(1):29-38.

8. Rocha AL, Reis FM, Taylor RN. Angiogenesis and endometriosis. Obstet Gynecol Int. 2013;2013:859619.

9. Hopwood D, Levison DA. Atrophy and apoptosis in the cyclical human endometrium. J Pathol. 1976;119(3):159-66.

10. Dmowski WP, Ding J, Shen J, Rana N, Fernandez BB, Braun DP. Apoptosis in endometrial glandular and stromal cells in women with and without endometriosis. Hum Reprod. 2001;16(9):1802-8.

11. Gebel HM, Braun DP, Tambur A, Frame D, Rana N, Dmowski WP. Spontaneous apoptosis of endometrial tissue is impaired in women with endometriosis. Fertil Steril. 1998;69(6):1042-7.

12. Donnez J, Smoes P, Gillerot S, Casanas-Roux F, Nisolle M. Vascular endothelial growth factor (VEGF) in endometriosis. Hum Reprod. 1998;13(6): 1686-90.

13. Young VJ, Ahmad SF, Brown JK, Duncan WC, Horne AW. Peritoneal VEGF-A expression is regulated by TGF- $\beta 1$ through an ID1 pathway in women with endometriosis. Sci Rep. 2015;5:16859.

14. Nakamura T. Structure and function of hepatocyte growth factor. Prog Growth Factor Res. 1991;3(1):67-85.

15. Delbandi AA, Mahmoudi M, Shervin A, Akbari E, Jeddi-Tehrani M, Sankian M, et al. Eutopic and ectopic stromal cells from patients with endometriosis exhibit differential invasive, adhesive, and proliferative behavior. Fertil Steril. 2013;100(3):761-9.

16. Kokhaei P, Abdalla AO, Hansson L, Mikaelsson E, Kubbies M, Haselbeck A, et al. Expression of erythropoietin receptor and in vitro functional effects of epoetins in B-cell malignancies. Clin Cancer Res. 2007;13(12):3536-44.

17. Meresman GF, Vighi S, Buquet RA, Contreras-Ortiz O, Tesone M, Rumi LS. Apoptosis and expression of $\mathrm{BCl}-2$ and $\mathrm{Bax}$ in eutopic endometrium from women with endometriosis. Fertil Steril. 2000;74(4):760-6.

18. Vaskivuo TE, Stenbäck F, Karhumaa P, Risteli J, Dunkel L, Tapanainen JS. Apoptosis and apoptosis-related proteins in human endometrium. Mol Cell Endocrinol. 2000;165(1-2):75-83.

19. Agic A, Djalali S, Diedrich K, Hornung D. Apoptosis in endometriosis. Gynecol Obstet Investig. 2009;68(4):217-23.

20. Di Nisio V, Rossi G, Di Luigi G, Palumbo P, D'Alfonso A, lorio R, et al. Increased levels of proapoptotic markers in normal ovarian cortex surrounding small endometriotic cysts. Reprod Biol. 2019;19(3):225-9.

21. Harada M, Suganuma N, Furuhashi M, Nagasaka T, Nakashima N, Kikkawa F, et al. Detection of apoptosis in human endometriotic tissue. Mol Hum Reprod. 1996;2(5):307-15.

22. Iwabe T, Harada T, Tsudo T, Nagano Y, Yoshida S, Tanikawa M, et al. Tumor necrosis factor-a promotes proliferation of endometriotic stromal cells by inducing interleukin-8 gene and protein expression. J Clin Endocrinol Metab. 2000:85(2):824-9.

23. Oosterlynck DJ, Meuleman C, Waer M, Koninckx PR. Transforming growth factor-beta activity is increased in peritoneal fluid from women with endometriosis. Obstet Gynecol. 1994;83(2):287-92.
24. Garcia-Velasco JA, Mulayim N, Kayisli UA, Arici A. Elevated soluble Fas ligand levels may suggest a role for apoptosis in women with endometriosis. Fertil Steril. 2002;78(4):855-9.

25. Garcia-Velasco JA, Arici A, Zreik T, Naftolin F, Mor G. Macrophage derived growth factors $m$ odulate Fas ligand expression in cultured endometrial stromal cells: a role in endometriosis. Mol Hum Reprod. 1999:5(7):642-50.

26. Selam B, Kayisli UA, Garcia-Velasco JA, Akbas GE, Arici A. Regulation of fas ligand expression by IL-8 in human endometrium. J Clin Endocrinol Metab. 2002:87(8):3921-7.

27. Depalo R, Cavallini A, Lorusso F, Bassi E, Totaro I, Marzullo A, et al. Apoptosis in normal ovaries of women with and without endometriosis. Reprod BioMed Online. 2009;19(6):808-15.

28. Otsuki Y, Li Z, Shibata MA. Apoptotic detection methods-from morphology to gene. Prog Histochem Cytochem. 2003;38(3):275-339.

29. Suganuma N, Harada M, Furuhashi M, Nawa A, Kikkawa F. Apoptosis in human endometrial and endometriotic tissues. Horm Res. 1997;48(Suppl. 3):42-7.

30. Hassa H, Tanir HM, Tekin B, Artan S, Dundar E, Kirilmaz SD, et al. Apoptosis patterns in eutopic and ectopic endometrium, adhesions and normallooking peritoneum from women with or without endometriosis. Arch Gynecol Obstet. 2009;280(2):195-9.

31. Jones RK, Searle RF, Bulmer JN. Apoptosis and bcl-2 expression in normal human endometrium, endometriosis and adenomyosis. Hum Reprod. 1998; 13(12):3496-502.

32. Zubor P, Hatok J, Galo S, Dokus K, Klobusiakova D, Danko J, et al. Antiapoptotic and pro-apoptotic gene expression evaluated from eutopic endometrium in the proliferative phase of the menstrual cycle among women with endometriosis and healthy controls. Eur J Obstet Gynecol Reprod Biol. 2009;145(2):172-6.

33. Oltval ZN, Milliman CL, Korsmeyer SJ. BCl-2 heterodimerizes in vivo with a conserved homolog, Bax, that accelerates programed cell death. Cell. 1993; 74(4):609-19.

34. Goumenou A, Panayiotides I, Matalliotakis I, Vlachonikolis I, Tzardi M, Koumantakis E. BCl-2 and Bax expression in human endometriotic and adenomyotic tissues. Eur J Obstet Gynecol Reprod Biol. 2001;99(2):256-60.

35. Devarajan E, Sahin AA, Chen JS, Krishnamurthy RR, Aggarwal N, Brun AM, et al. Down-regulation of caspase 3 in breast cancer: a possible mechanism for chemoresistance. Oncogene. 2002;21(57):8843-51.

36. Wei WD, Ruan F, Tu FX, Zhou CY, Lin J. Expression of suppressor of cytokine signaling-3 and caspase-3 in endometriosis and their correlation. Zhonghua Bing Li Xue Za Zhi. 2013;42(8):515-8.

37. Smith SK. Vascular endothelial growth factor and the endometrium. Hum Reprod. 1996;11(suppl_2):56-61.

38. Becker CM, D'Amato RJ. Angiogenesis and antiangiogenic therapy in endometriosis. Microvasc Res. 2007;74(2-3):121-30.

39. McLaren J. Vascular endothelial growth factor and endometriotic angiogenesis. Hum Reprod Update. 2000;6(1):45-55.

40. Cho S, Choi YS, Jeon YE, Im KJ, Choi YM, Yim SY, et al. Expression of vascular endothelial growth factor (VEGF) and its soluble receptor-1 in endometriosis. Microvasc Res. 2012:83(2):237-42.

41. Rizner TL. Diagnostic potential of peritoneal fluid biomarkers of endometriosis. Expert Rev Mol Diagn. 2015;15(4):557-80.

42. Rashidi BH, Sarhangi N, Aminimoghaddam S, Haghollahi F, Naji T, Amol MM, et al. Association of vascular endothelial growth factor (VEGF) gene polymorphisms and expression with the risk of endometriosis: a casecontrol study. Mol Biol Rep. 2019:46(3):3445-50.

43. Yerlikaya G, Balendran S, Pröstling K, Reischer T, Birner P, Wenzl R, et al. Comprehensive study of angiogenic factors in women with endometriosis compared to women without endometriosis. Eur J Obstet Gynecol Reprod Biol. 2016;204:88-98.

44. Danastas K, Miller EJ, Hey-Cunningham AJ, Murphy CR, Lindsay LA. Expression of vascular endothelial growth factor a isoforms is dysregulated in women with endometriosis. Reprod Fertil Dev. 2018;30(4):651-7.

45. Di Carlo C, Bonifacio M, Tommaselli GA, Bifulco G, Guerra G, Nappi C. Metalloproteinases, vascular endothelial growth factor, and angiopoietin 1 and 2 in eutopic and ectopic endometrium. Fertil Steril. 2009;91(6):2315-23.

46. Filippi I, Carrarelli P, Luisi S, Batteux F, Chapron C, Naldini A, et al. Different expression of hypoxic and angiogenic factors in human endometriotic lesions, Reprod Sci. 2016:23(4):492-7.

47. Takehara M, Ueda M, Yamashita Y, Terai Y, Hung YC, Ueki M. Vascular endothelial growth factor a and $C$ gene expression in endometriosis. Hum Pathol. 2004;35(11):1369-75. 
48. Tan XJ, Lang JH, Liu DY, Shen K, Leng JH, Zhu L. Expression of vascular endothelial growth factor and thrombospondin-1 mRNA in patients with endometriosis. Fertil Steril. 2002;78(1):148-53.

49. Bourlev V, Volkov N, Pavlovitch S, Lets N, Larsson A, Olovsson M. The relationship between microvessel density, proliferative activity and expression of vascular endothelial growth factor-a and its receptors in eutopic endometrium and endometriotic lesions. Reproduction. 2006;132(3):501-9.

50. Li YZ, Wang LJ, Li X, Li SL, Wang JL, Wu ZH, et al. Vascular endothelial growth factor gene polymorphisms contribute to the risk of endometriosis: an updated systematic review and meta-analysis of 14 case-control studies. Genet Mol Res. 2013;12(2):1035-44.

51. Yoshida S, Harada T, Mitsunari M, Iwabe T, Sakamoto Y, Tsukihara S, et al. Hepatocyte growth factor/met system promotes endometrial and endometriotic stromal cell invasion via autocrine and paracrine pathways. J Clin Endocrinol Metab. 2004:89(2):823-32.

52. Khan KN, Masuzaki H, Fujishita A, Hamasaki T, Kitajima M, Hasuo A, et al. Association of interleukin-6 and estradiol with hepatocyte growth factor in peritoneal fluid of women with endometriosis. Acta Obstet Gynecol Scand. 2002:81(8):764-71.

53. Zong LL, Li YL, Song ST, Jiang ZF, Zhao J. Expression of hepatocyte growth factor and its receptor c-met gene in the endometrium of women with endometriosis. Di Yi Jun Yi Da Xue Xue Bao. 2004;24(6):619-22.

54. Fukaya T, Sugawara J, Yoshida H, Murakami T, Yajima A. Intercellular adhesion molecule-1 and hepatocyte growth factor in human endometriosis: original investigation and a review of literature. Gynecol Obstet Investig. 1999:47(Suppl. 1):11-7.

55. Arablou T, Delbandi AA, Khodaverdi S, Arefi S, Kolahdouz-Mohammadi R, Heidari S, et al. Resveratrol reduces the expression of insulin-like growth factor-1 and hepatocyte growth factor in stromal cells of women with endometriosis compared with nonendometriotic women. Phytother Res. 2019;33(4):1044-54.

56. Khan KN, Kitajima M, Hiraki K, Fujishita A, Sekine I, Ishimaru T, et al. Immunopathogenesis of pelvic endometriosis: role of hepatocyte growth factor, macrophages and ovarian steroids. Am J Reprod Immunol. 2008; 60(5):383-404

57. Xin X, Yang S, Ingle G, Zlot C, Rangell L, Kowalski J, et al. Hepatocyte growth factor enhances vascular endothelial growth factor-induced angiogenesis in vitro and in vivo. Am J Pathol. 2001;158(3):1111-20.

\section{Publisher's Note}

Springer Nature remains neutral with regard to jurisdictional claims in published maps and institutional affiliations.

\section{Ready to submit your research? Choose BMC and benefit from:}

- fast, convenient online submission

- thorough peer review by experienced researchers in your field

- rapid publication on acceptance

- support for research data, including large and complex data types

- gold Open Access which fosters wider collaboration and increased citations

- maximum visibility for your research: over $100 \mathrm{M}$ website views per year

At $\mathrm{BMC}$, research is always in progress.

Learn more biomedcentral.com/submissions 